UDC 627.01

DOI https://doi.org/10.32838/2663-5941/2021.4/36

Danylyan A.H.

Danube Institute

of National University "Odessa Maritime Academy"

Tiron-Vorobiova N.B.

Danube Institute

of National University "Odessa Maritime Academy”

Maslov I.Z.

Danube Institute

of National University "Odessa Maritime Academy"

Kulahin E.O.

Danube Institute

of National University "Odessa Maritime Academy"

\title{
IDENTIFICATION OF OPTIMIZATION APPROACHES TO THE DEEP HEAT RECOVERY PROCESS OF MARINE DIESEL ENGINES
}

The idea of creating steam and gas plants, which use as combustion products of fuel combustion and water vapor, was first expressed by French scientist Sadie Carnot in 1824 in his work "Reflections on the driving force of fire and machines capable of developing this force". Carnot proposed a scheme of a reciprocating steam-gas plant and substantiated the main condition for the creation of efficient steam-gas plants - the use of fuel combustion products as a working fluid in the field of high temperatures with simultaneous utilization of waste heat gases to obtain working steam. With the development of steam and gas turbines, it became possible to put this idea into practice. The study of modern heat recovery power plants of ships of the merchant marine of the World in this article is presented. Using modern scientific achievements in the areas of the possible use of low-temperature heat in hydro-steam turbines HST, Professor V.A. Zysin made specific proposals in relation to the merchant marine of the world.

Identified priority areas for more electricity from waste heat recovery are presented: the further steps with a view to improving the deeper heat recovery power plants vessel.

It is proposed for the first time, to use the heat of the inner loop of the ship's main engine for improvement using nanotechnology HST. The study presents global analogs of savings. It is proved that the choice of the optimal solution must be approached comprehensively, considering all the components. The work presents the principle of action HST of V. Zysin, characteristics are given that optimally distinguish it from other analogs.

In addition, the study proposes a uniquely effective approach to the process of deep heat recovery of marine diesel engines, developed by scientists of the Danube Institute of National University "Odessa Maritime Academy", which is versatile because it is suitable for use in different latitudes. A thermal column was developed and improved.

Key words: merchant marine fleet, utilization of waste heat gases, the main power plant, the auxiliary steam turbine generator, an auxiliary gas turbine exhaust gas, hydro-steam turbine, low-temperature heat, utilization boiler.

Introduction. At the present stage, the problem of energy efficiency requires more and more attention. This is due to a significant increase in the price of energy and increased concern for the environment.

This issue is very relevant. So, the work of V. Kiris is devoted to considering trends in increasing the energy efficiency of transport. After all, it is transport that represents the region with the highest fuel and energy consumption, which means this issue requires special attention [1].

A. Solovyov, M. Chirkova, N. Popov study ways to increase the efficiency of ship power plants.
Emphasis is placed on the reasons for the insufficient use of secondary energy resources on ships, primarily the lack of automated control systems for integrated heat recovery systems, which leads to a decrease in its economic efficiency [2].

The study by A. Volyncev, A. Sobolenko reveals the potential use of a heat pump and a heat exchanger in a ship's heating system. The principle of operation of a heat pump unit utilizing low-potential secondary heat resources of the main engine is characterized [3]. The article by V. Vedruchenko and V. Krainov proves 
the feasibility of using contact heat exchangers instead of generally accepted surface heat exchangers for utilization of charge air heat [4].

A. Danylyan, V. Chymshyr, I. Vlasov, A. Naydyonov are convinced that traditional approaches to the utilization of heat recovery do not allow the use of this heat in the form of a steam-water mixture on the line: consumers are the condenser of the steam boiler. The authors analyze ways to improve the hydro-steam turbine in order to more deeply utilize the heat of the ship's power plants [5].

A method of utilizing the heat of exhaust gases from the main diesel engines of a ship of Project 630.2 Kazan City in a thermoelectric generator is presented in development by S. Vinogradov, K. Halykov, K.D. Nguyen [6]. The authors are sure that the use of thermoelectric generators that operate based on the energy of the heat of the exhaust gases of a diesel engine is an effective method of increasing the efficiency of heat use in ship power plants (SPP).

The aim of the article is to determine, based on analysis of specialized scientific literature, the most effective approaches to the process of deep heat recovery of marine diesel engines.

Materials and methods. Expenditures for the operation of power plants of marine vessels account for $70-80 \%$ of total costs [1]. Based on this, improving energy efficiency SPP is of great importance. It is advisable to recall that energy efficiency is understood to mean the rational use of energy or the use of less energy to ensure a specified level of product production during production processes. Utilization of the secondary heat resources of the ship's main engine is traditionally one of the main technologies for improving the integrated use of fuel for ship power plants.

Specialists according to the classification of heat recovery systems (HRS) distinguish them on the basis of such signs: the kind of source of secondary heat; kind of coolant; destination; type of recycling equipment; depths of heat recovery [2].

We agree with the opinion of V. Kiris that at the present stage, waste heat recovery systems are becoming increasingly complex. In the best systems, the efficiency of using waste heat reaches $60 \%$ due to the use of more efficient utilization boilers, heating of feed water, utilization of turbine generators of two pressures, etc. At present, there are several ways to utilize heat: utilization of exhaust gas energy, utilization of the heat of the coolant, utilization of the heat of the engine oil [1].

The analysis of the reasons for the insufficient use of secondary energy resources on ships is complex, and the main reasons can be called the following:
- designers, customers, and ship owners do not pay appropriate attention to this area, because they are not ready to evaluate all the advantages of HRS and integrated heat recovery systems (IHRS);

- the customer, when building the vessel, focuses on minimizing capital investments without calculating operating costs, including not considering the possible savings in the fuel used for heating and hot water supply;

- operators are skeptical of HRS, as the number of serviced systems is increasing, and undesirable phenomena associated with the quality of the feed water accompany steam utilization systems;

- lack of automated control systems IHRS, which leads to a decrease in economic efficiency IHRS and the difficulties of integrating into a management system SPP [2].

A sufficiently effective way to increase the level of use of energy received in the engine during fuel combustion is to utilize the heat of the exhaust gases, charge air, and freshwater engine cooling systems. V. Vedruchenko, V. Krainov note that the use of an evaporative method for cooling charge air allows the energy expended to compress air to be completely returned to the engine cycle. In addition, the use of contact air coolers in modern highly efficient diesel engines with increased pressurization by $10 \%$ increases their efficiency compared to cooling in traditional surface charge air coolers. In this way, the possibilities of utilizing the heat of each source are determined by the boost and power of the engines that make up the diesel power plant and the heat and electric energy needs of the diesel vehicle or other consumer [4].

A. Volyncev, A. Sobolenko determine the most preferable source of the utilization of the heat resources of the main marine engine for the operation of the heat pump installation is freshwater, cooling the shirts of the cylinders of the main engine, having a temperature at the exit of the diesel engine of $80-85^{\circ} \mathrm{C}$ [3]. In general, the introduction of heat pump heat and cold supply systems is a very effective energy conservation policy tool for fishing and navy vessels, which allows not only to save energy resources for consumers but also to reduce the load on the ship's centralized energy-saving system, as well as reduce emissions of traditional organic combustion products into the atmosphere fuel.

The following development is also of interest. Mitsubishi Heavy Industries, Ltd. (MHI) offers a super-waste heat recovery system for the main marine power plant (MMPP) as a solution to strengthen environmental restrictions and increase demand for improved fuel oil consumption. Its 
essence is as follows. In a conventional combined system in which the exhaust gas from the main diesel engine is used in an exhaust gas economizer and in a steam turbine generation system, all exhaust gas from a diesel engine passes through a turbocharger. This super-waste heat recovery system consists of a conventional combined system and a power turbine (gas turbine), which uses a portion of the exhaust gas with an automatic overrunning clutch between the power turbine and the steam turbine [7].

Results and discussion. The working thermal scheme proposed by A. Danylyan, V. Chymshyr, I. Vlasov, and A. Naydyonov for the deep utilization of low-temperature heat by its own versatility is able to satisfy all the ship's operating modes in various latitudes of the World Ocean.

The main marine engine has exhaust gases after the gas turbine boost GTB with parameters of $320-340^{\circ} \mathrm{C}$ in the nominal power mode, transferring them to a combined steam boiler, which operates autonomously on diesel fuel, and as a waste boiler, it works from exhaust gases GTB main engine. The steam received in the steam boiler goes to the distributor of ship consumers. All ship consumers have varying degrees of thermal use of steam with parameters of $260-280^{\circ} \mathrm{C}$. The largest heat consumers on board are steam heaters for heavy fuel storage tanks, whose viscosity at $50^{\circ} \mathrm{C}$ is 335 centistokes (cSt) [5].

This thermal scheme allows you to work in any latitude of the vessel. A system is provided for operation HST from the internal circuit of the engine, having previously closed the collector of the exhaust steam and starting the consumption of the coolant from the main engine in its nominal operating mode. The coolant in this mode is the water of the internal engine cooling circuit with parameters $85-95^{\circ} \mathrm{C}$ [3]. Due to the versatility of the scheme, you can use a marine combined auxiliary boiler with autonomous fuel combustion to maintain the desired temperature in the cooling circuit of the main engine for efficient operation HST [5]. Using a thermostatic valve, you can raise and lower the temperature of the internal cooling circuit of the main engine.

When working in mid-temperate climatic latitudes, the return of the steam-water mixture will be $130-115^{\circ} \mathrm{C}$, which can be successfully used in HST. In the northern latitudes, in the context of increasing steam consumption and the need to maintain the heat balance of the entire thermal circuit in the proposed scheme, it will be sufficient to open the distributor valve and pass more heat through the remote-control valve to the heat exchanger. This will simultaneously increase the temperature of the condenser. HST and a warm boiler box will increase the temperature regime of the auxiliary combined boiler and the entire thermal circuit [5]. This operating mode can be used with an autonomous fuel combustion system of the boiler.

In order to maximize the use of low-temperature heat, it is proposed to mount a thermal column with a coil with a high degree of heat removal into the fuel storage tank. It heats up to the desired temperature only the amount of fuel that will be used by the main engine and diesel generators. The remaining volume of fuel in the storage tank will be heated to a lower temperature.

The use of traditional heating of heavy fuel storage tanks is carried out by coils along the entire bottom of the fuel tank, which is extremely impractical - this leads to large heat losses and a decrease in the return steam temperature.

The heat column must be sized considering the capacity of the fuel transfer pump to guarantee the supply of fuel to the separators. It will also be provided with automated control of the coolant supply to the column heater and the fuel tank coil. The heat supply will be controlled by an electronic control unit using remote thermostatic valves capable of differentiating heat with great accuracy between the heat column and the bottom coils of the ship's fuel tanks [5].

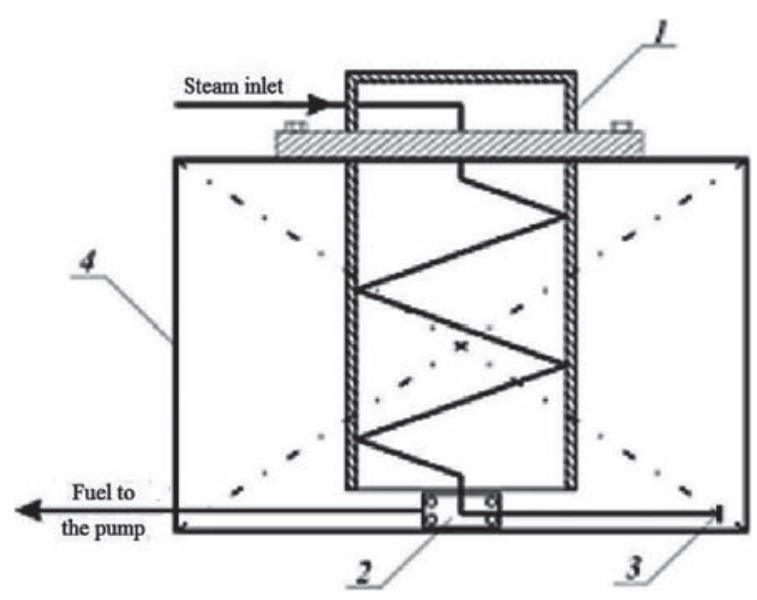

Fig. 1. Heat column of the heavy fuel storage tank: 1 - column body; 2 - fuel receiving Steiner; 3 - coil for heating the bottom of the fuel storage tank; 4 - heavy fuel storage tank

Thus, the heat column is a unique development of the team of authors: A. Danylyan, V. Chymshyr, I. Vlasov, A. Naydyonov, which is really capable of qualitatively optimizing the heating of heavy fuel in its storage tanks. The result is a significant increase in the efficiency of the thermal scheme for utilizing low-temperature heat and real cost savings. 


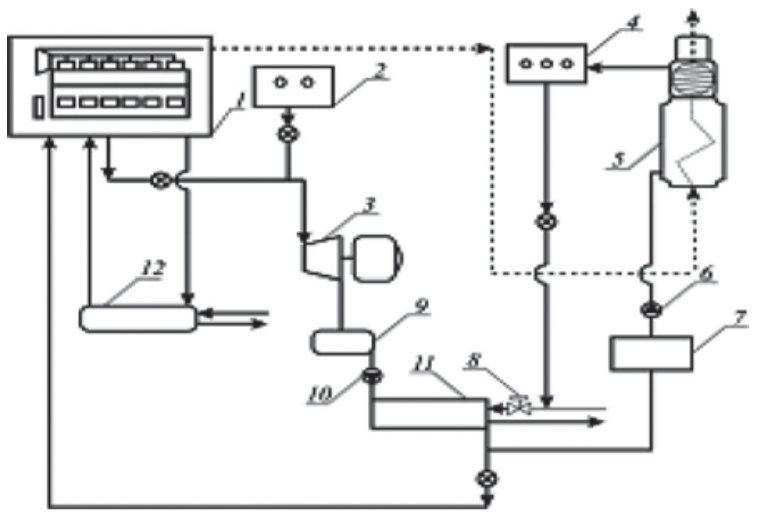

Fig. 2. Ship thermal scheme for the deep utilization of low temperature heat: 1 - main engine; 2 - a collection of spent steam; 3 - GPT with a power generator; 4 - working steam to the consumer distributor; 5 - combined steam boiler; 6 - boiler feed pump;

7 - warm boiler box; 8 - remote thermostatic valve; 9 - GPT capacitor; 10 - condenser pump with an ejector; 11 - heat exchanger (cooler); 12 - cooler of the internal circuit of the main engine

HST works on the principle of a Segner wheel, which is distinguished by the simplicity of the circuit and design. In work, HST two main physical phenomena are realized. The first is rotation HST due to the action of reactive forces (moments) of the jets of the resulting two-phase mixture. The second is the formation of a two-phase mixture in a stream of water not heated to saturation when the pressure of hot water in the stream drops to the pressure of saturated vapor. It is the phenomenon of vaporization of water in the stream that allows in installation with HST. It is useful to utilize the enthalpy stored in heated water by generating electricity using an electric generator located on the turbine shaft. When developing hydro-steam turbines, the action of inertial forces (centrifugal and Coriolis forces) should be considered, which, depending on the configuration of the radial channel, can have both positive and negative effects on the torque of the turbine. For the useful use of Coriolis and centrifugal forces, a turbine with a radial channel, described by the helix equation with a change in the direction of movement of the working fluid, is proposed.

The basis of this technical solution is the task of improving a jet turbine, in which a rectilinear radial section of the channel is made in the form of a cylinder, in which a closed screw channel is placed. A jet turbine contains a rotor with channels for supplying a working fluid to nozzles connected to a cavity located on the turbine shaft. The channel contains a rectilinear radial section made in the form of a cylinder, in which a helical channel is located, consisting of alternating lifting and lowering arc channels. The conjugation points of the arc channels between themselves are on opposite sides of the cylinder while being offset relative to each other by the value of the nominal pitch. The last lowering arc channel is offset from the previous one by a step that differs from the nominal one and is connected to the diametrical channel.

The turbine works as follows: a working fluid (water, steam, gas), passing successively through alternating lifting and lowering channels creates a Coriolis force concentrated in the middle of each arc lowering channel, which occurs when there is a flow velocity and a peripheral speed of rotation of the turbine, the projection of which creates torque and in the middle of each lifting channel the braking torque of the turbine, which, basically, cancel each other, significantly reducing the negative impact of the aforementioned force on the torque of the turbine. In addition, in the places where alternating lifting and lowering channels are interconnected, which are at the maximum and minimum distances from the longitudinal axis of the turbine shaft, additional centrifugal forces arise, directed in opposite directions, the projections of which result in additional torque coinciding with the main torque of the turbine, created by the reactive force of the twophase jet flowing out of the nozzle and the eccentric centrifugal force created by the flow of the working fluid in the center of the curved section. As a result, the total torque of the turbine and, consequently, its power increase. Calculation of the flow of the working fluid in a 3-dimensional spatial spiral channel presents great difficulties, therefore one has to resort to simplifying representations, one of which is a mathematical description of the expansion of a spiral channel with linear approximation. Each turn consists of two branches, the lifting and lowering, the angle of the helix is denoted by $\alpha$, descent angle $-\beta$ (projections of the angles of the lifting and lowering branches to the $x_{0} y$ plane, respectively, are depicted on the scan). The angle of descent of the lower branch of the last turn is denoted by $\theta_{l}$, the offset of this section is necessary to prevent the intersection of the diametric channel connecting the lower branch of the last turn of the screw channel and the additional curved channel with the previous turn. The scan shows characteristic points marking the beginning, completion, and middle of each turn and half-turn of the helical channel. Inertial forces (centrifugal $F_{c f}$ and Coriolis $F_{c o r}$ ) and components of these forces $F_{c f}$ and $F_{c o r}$ acting in or against the direction of motion of the turbine rotor and creating torque or braking moments are indicated at characteristic points $[8,9]$. 
Heat exchangers, in which the heating medium is superheated steam, and the heated water, are described by the heat balance equation:

$$
G_{n} *\left(i n_{1}-i n_{2}\right) \bullet \eta m a=G_{b} \bullet c_{b} \bullet\left(t b_{2}-t b_{1}\right),
$$

where: $G_{n}$ is the steam flow rate, $\mathrm{kg} / \mathrm{s}$,

$i n_{1}, i n_{2}$ - vapor enthalpy at the inlet and outlet of the apparatus, $\mathrm{J} / \mathrm{kg}$,

yma - coefficient of performance (CP) of the heat exchanger,

$G_{b}$ is the consumption of heated water, $\mathrm{kg} / \mathrm{s}$,

$c_{b}$ - specific heat of water, $\mathrm{J} / \mathrm{kg} \mathrm{deg}$,

$t b_{1}, t b_{2}$ - initial and final water temperature, ${ }^{\circ} \mathrm{C}$.

It is assumed that the heating medium at the outlet of the heat exchangers is a condensate with a temperature equal to the saturation temperature at the pressure of the heating steam in the apparatus. The system of regenerative heating of feed water includes deaerators, and the deaerators themselves are nodes for mixing water and steam flows. The heat balance equation for these devices can be written as:

$$
G_{n} \bullet i_{\mathrm{n}} \bullet \eta d a+\Sigma G_{j} \bullet i_{j}=0,
$$

where: $\eta d a-\mathrm{CP}$ of the deaerator considering heat loss to the environment,

$G_{j}, i_{j}$ are the flow rate and enthalpy of water and steam flows entering or leaving the deaerator along the jth branches, $\mathrm{kg} / \mathrm{s}$ and $\mathrm{J} / \mathrm{kg}$, respectively (Dyakun and Kozar, 2013).

V. Zysin, in his book Combined Cycle Units and Cycles, notes that the realization of an optimal triangular cycle is possible only in an engine capable of "working on a dropping liquid boiling during expansion". The flow of such fluid to the blades of a turbine wheel from a fixed nozzle is inefficient since the channel for the movement of a two-phase flow in such structures inevitably turns out to be curved,

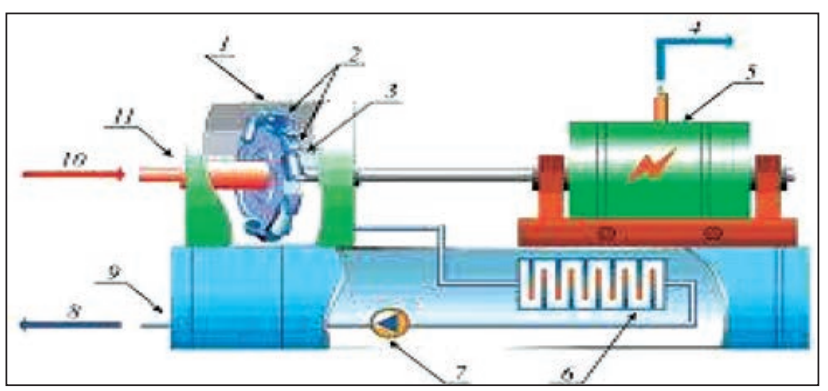

Fig. 3. Model GPT V. A. Zysin to generate electricity from low temperature heat: 1 - hydro-steam turbine;

2 - Laval nozzle; 3 - volumetric boiling creates a steam-water jet that rotates the generator rotor; 4 electricity; 5 - electric generator; 6 - boiler-condenser;

7 - condenser pump; 8 - to the network; 9 - spent steam is condensed and returned to the network; 10 hot water; 11 - hot water is supplied through channels on the rotor to the casing with low pressure which causes irreversible losses and causes wear to streamlined surfaces.

An alternative was a jet turbine with rotating Laval nozzles, from which a boiling stream of superheated water flows. This flow creates a jet thrust that accelerates the nozzle and spins the turbine.

At the same time, V. Zysin draws attention to the need to observe the following conditions: the process of vaporization should be carried out only in the expanding part of the Laval nozzle; to a minimum nozzle cross-section, the pressure and shape of the flow channel must be such that there is neither cavitation nor vaporization at local pressure drops; behind the Laval nozzle, a two-phase supersonic flow should not meet moving parts subject to wear.

Thus, superheated water must enter the turbine rotor through the hollow shaft and move first along its axis, and then to the nozzles on the periphery. The thermodynamic process taking place in such an installation is a variation of the classical process for heat engines.

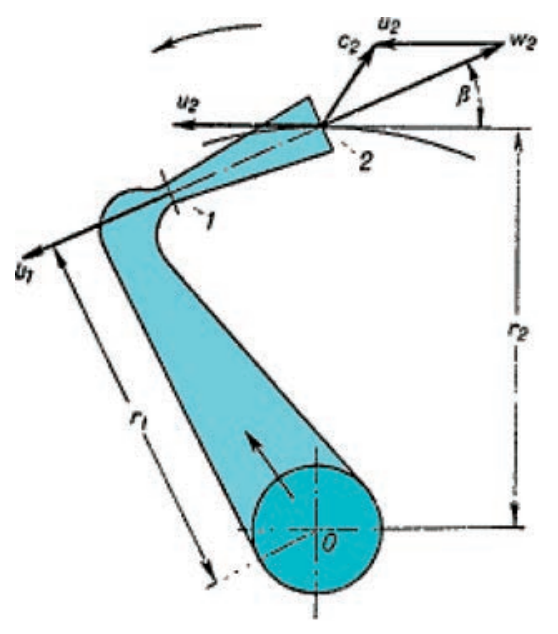

Fig. 4. The decomposition of the forces of the coolant in the nozzle apparatus of a hydro-steam turbine

In Fig. 4, the coolant entering the nozzle apparatus is decomposed into vectors of fluid flow and rotor disk, where $C_{2}$ is the vector of the absolute flow velocity; $U_{2}$ is the vector of the peripheral flow velocity; $W_{1}$ is the vector of the relative flow rate; $W_{2}$ is a vector of actual flow rate; $U_{I}$ is the vector of the peripheral speed of the rotor disc; $R_{l}$ is the distance from the inlet of the working fluid of the nozzle apparatus to its outlet; $R_{2}$ is the length from the inlet of the working fluid to the convergent nozzle; $\beta$ is the angle formed by the axis of the vector $U_{2}$ and the vector $W_{2}$.

The working fluid flow, entering the rotor shaft channel, passes into the disk nozzles, where, passing the nozzle curvature with minimal resistance, it is directed to its tip [5]. The flow rate of the working 
fluid significantly increases in the converging part of the Laval nozzle, which, already with the transition to the expanding part, makes it possible for the working fluid to turn into steam, creating all the conditions for obtaining the rotating moment of the rotor shaft. distance from the inlet of the working fluid of the nozzle apparatus to its outlet.

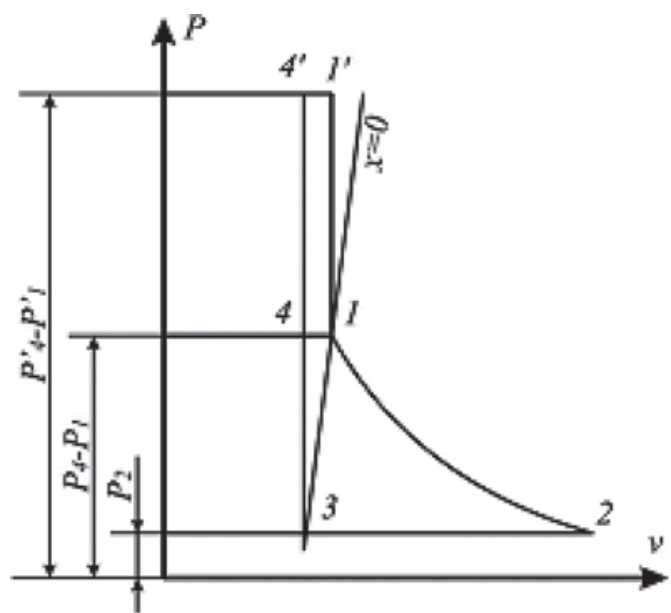

Fig. 5. GPT turbine thermodynamic cycle

Section $1^{\prime} \rightarrow 1$ corresponds to the narrowing part of the Laval nozzle (pressure drop during flow acceleration due to narrowing of the channel section in accordance with Bernoulli law), and section $1 \rightarrow 2$

- to its expanding part, where intense vaporization occurs, in section $2 \rightarrow 3$ condensation of the generated steam, section $3 \rightarrow 4-$ is an increase in water pressure and it's overheating in front of the turbine rotor to a state close to the equilibrium between steam and liquid (while maintaining the liquid state of aggregation), section $4 \rightarrow 4$ '.

Thus, all the useful work of the turbine is carried out due to the external energy spent on increasing the pressure and heating the water in section $3 \rightarrow 4$. In general, V. Zysin estimates "possible CP" at 40-50\% and notes that in this case, it will be a "promising element of electricity production schemes".

The main marine engine with an efficiency of 50\% has exhaust gases after the pressurized gas turbine GTN with parameters $320-340^{\circ} \mathrm{C}$ in the nominal power mode, transferring them to a combined steam boiler, which operates autonomously on diesel fuel, and as a waste boiler operates from the exhaust gases of the GTN of the main engine. The resulting steam in the steam boiler goes to the ship's consumer distributor. All ship consumers have varying degrees of thermal utilization of steam with parameters $260-280^{\circ} \mathrm{C}$. The largest consumer of heat on a ship is the steam heaters of heavy fuel storage tanks, the viscosity of which at $50^{\circ} \mathrm{C}$ is $335 \mathrm{cSt}$. Therefore, in different latitudes of navigation, there will be different heat consumption for heating heavy fuel in storage tanks. Working in the middle temperate climatic latitudes, the return of the steam-water mixture will be $130-115^{\circ} \mathrm{C}$, which can be used in the gas turbine engine. Imagine the standard power of the main marine engine, which is 13.200 $\mathrm{kW}$. Taking into account the efficiency of the engine, which is $50 \%$ and the fact that the remaining $50 \%$ (about $6500 \mathrm{~kW}$ ) is spent on heating fuel, oil, water, as well as heat radiation and exhaust, from the steamwater mixture returned after heating consumers, we will get about $20 \%$ from unused heat $(1300 \mathrm{~kW})$, which, if we take into account the efficiency of the gas turbine generator, $40 \%$ will mean that we will save about $500 \mathrm{~kW}$ of unused heat.

Effective efficiency of the hydro-steam turbine:

$\eta_{e}=N_{e} / Q=\eta_{i} \eta_{m}=\eta_{t} \eta_{r e}$, (3)

where: $N_{e}$ is the effective power developed by the turbine on the coupling

connecting the turbo shaft bins with the shaft of the driven machine,

$Q$ is the consumed heat, $\mathrm{J}$,

$\eta_{i}$ is the absolute internal efficiency,

$\eta_{m}$ is the mechanical efficiency,

$\eta_{t}$ is the thermal efficiency,

$\eta_{r e}$ is the relative effective efficiency.

Effective efficiency of the main marine engine:

$\eta_{e}=A \cdot L_{e} / Q_{1}$,

where: $L_{e}$ is the efficient work done per cycle,

$A$ is the effective work,

$Q_{1}$ is the amount of heat received from the heater, $\mathrm{J}$.

Conclusions. Thus, the problem of finding approaches to the process of deep heat recovery of marine diesel engines is very relevant in modern realities. The study presents global analogs of savings. It is proved that the choice of the optimal solution must be approached comprehensively, considering all the components. The work presents the principle of action HST of V. Zysin, characteristics are given that optimally distinguish it from other analogs. In addition, the study proposed a unique option developed by the team of Danube Institute of National University "Odessa Maritime Academy", which is distinguished by its versatility, because Suitable for use in various latitudes. A thermal column was developed.

\section{References:}

1. Кіріс В.А. Тенденції енергоефективності на транспорті. Морські електростанції. 2014. № 34. C. $145-154$. 
2. Соловйов А.В., Чиркова М.М., Попов Н.Ф. Підвищення ефективності роботи морських електростанцій. Вісник Астраханського державного технічного університету. Серія «Морська інженерія та технологї̈». 2018. № 4. С. 101-106.

3. Волинцев А.В., Соболенко А.Н. Використання теплових ресурсів головного суднового двигуна за допомогою теплового насосного агрегату. Вісник Державного університету морського та річкового флоту імені адмірала С.О. Макарова. 2016. № 5 (39). С. 144-150.

4. Ведрученко В.Р., Крайнов В.В. Вибір типу охолоджувача повітря для утилізації втрат тепла на дизельних електростанціях. Омський науковий вісник. 2007. № 1 (52). С. 97-102.

5. Нові напрями глибокої рекуперації тепла морських дизельних двигунів / А.Г. Данилян, В.І. Чимшир, І.В. Власов, А.І. Найдьонов. Вісник Одеського наиіонального морського університету. 2016. № 3 (49). C. 91-103.

6. Виноградов С.В., Галиков К.Р., Нгуен К.Д. Застосування термоелектричних генераторів як засіб утилізації відпрацьованого тепла морських дизельних двигунів. Вісник Астраханського держсавного технічного університету. Серія «Морська інженерія та технології». 2011. № 3. С. 78-83.

7. Розробка системи утилізації супервідходів та теплоти для морських дизельних двигунів / Ю. Ічікі, К. Ширайші, Т. Канабосі, Ю. Оно. Технічний огляд Mitsubishi Heavy Industries. 2011. № 48 (1). С. 17-21.

8. Булат А.Ф., Чемерис І.Ф., Пімоненко Д.Н. Теоретичні основи розробки гідро-парової турбіни 3 поперемінним рухом робочої рідини для утилізації надлишкового низькосортного тепла. Геотехнічна механіка : міжвідомчий збірник наукових праць. 2012. Вип. 97. С. 294-299.

9. Дякун І.Л., Козар І.Ю. Енергоефективність схем когенерації шахтного енергетичного комплексу. Геотехнічна механіка. 2013. № 110. С. 70-79.

\section{Данилян А.Г., Тірон-Воробйова Н.Б., Маслов І.З., Кулагін Е.О. ІДЕНТИФІКАЦІЯ ОПТИМІЗАЦІЙНИХ ПІДХОДІВ ДО ПРОЦЕСУ ГЛИБОКОЇ РЕКУПЕРАЦІЇ ТЕПЛА СУДНОВИХ ДИЗЕЛЬНИХ ДВИГУНІВ}

Ідея створення парогазових установок, які використовують як робочі тіла продукти згорання палива й водяний пар, уперше висловлена франиузьким ученим Саді Карно ще в 1824 році в праці «Роздуми про рушійну силу вогню і про машини, здатні розвивати иџю силу». С. Карно запропонував схему поршневоі парогазової установки й обтрунтував основну умову створення ефективних парогазових установок використання продуктів згорання палива як робочого тіла в галузі високих температур з одночасною утилізацією скидної теплоти газів для отримання робочої пари. У міру розвитку парових $і$ газових турбін виявилося можливим практичне здійснення иієї ідеї. У статті представлено дослідження сучасних теплоенергетичних електростаниій суден торгового флоту світу. Використовуючи сучасні наукові досягнення в галузях можливого використання низькотемпературного тепла в гідропарових турбінах (ГПТ), професор В. Зисін зробив конкретні пропозииії щодо торгового морського флоту світу.

Метою статі є представити визначені пріоритетні напрями отримання більшої кількості електроенергії за рахунок рекуперації відпрацьованого тепла: подальші кроки з метою вдосконалення більш глибокого рекупераційного теплового судна.

Уперше пропонується використовувати тепло внутрішньої петлі головного двигуна корабля для вдосконалення з використанням нанотехнологій ГПТ. У дослідженні представлено глобальні аналоги заомаджень. Доведено, що до вибору оптимального рішення варто підходити комплексно, ураховуючи всі компоненти. Представлено принцип дії ГПТ В. Зисіна, наведено характеристики, які оптимально відрізняють його від інших аналогів.

Крім того, запропоновано унікальний ефективний підхід до прочесу глибокої рекупераиії тепла морських дизельних двигунів, розроблений науковиями Дунайського інституту Національного університету «Одеської морської академії», який відрізняється своєю універсальністю, оскільки підходить для використання в різних широтах. Розроблено й удосконалено теплову колону.

Ключові слова: торгівельний морський флот, утилізація відпрачььваних теплових газів, головна енергетична установка, допоміжний паротурбінний генератор, вихлопний газ допоміжної газової турбіни, гідропарова турбіна, низькотемпературне тепло, утилізаиійний котел. 